\title{
Labour market flexibility and the quality of work: a case study of the retail industry
}

Peter Brosnan*

The view that labour market flexibility will lead to benefits for everyone is far from obvious. This paper analyses changes in retailing over the last decades. It finds that much flexibility has been achieved in the industry. Recent legislative changes have played an important role in these changes. Processes of deskilling, casualization, juvenalization and feminization are being intensified. The effects on the quality of working life for retail workers are examined. It is found that retail workers are having to pay a high price for the flexibilities achieved by their employers.

\section{Introduction}

A frequent assertion of the Business Roundtable and other employer lobby groups is that New Zealand has an inflexible labour market. Research by Harbridge and McCaw (1989), the Planning Council (1986) and others has cast severe doubt on the truth of this claim. Nonetheless, as Dannin (1990) shows, employer representatives continue to make this assertion in public (Treasury, 1984, 1987). The Reserve Bank and leading members of both the Labour and National Parties have also joined in the call for more labour market flexibility. More flexibility is one of the aims of the Employment Contracts Bill currently before Parliament. Despite the imminence of the Bill, and the frequency with which calls for more flexibility are made, the exact benefits of more flexibility are never spelt out. Nonetheless, it is usually asserted that a more flexible labour market will lead to an improved national economic performance, reflected in an improved balance of payments, reduced unemployment and less inflationary pressures.

The proponents of these views rarely, if ever, examine the consequences for workers of more flexibility. If the flexibilities sought by employers do indeed produce more jobs and economic growth, then there is potential for benefits to accrue to the working class. But the question which remains, and which is never answered, is how these gains, if they

* Industrial Relations Centre, Victoria University of Wellington. Much of the material on which this article is based was obtained while the author was a member of the Second Sweating Commission. Various retail employers provided further information. The author would like to thank the shop workers and others who gave evidence before the Commission, his fellow commissioners, officials of the New Zealand Distribution and General Workers Union, the Northern Distribution Union and the Distribution Workers Federation and the retail employers who provided information. The author would like to thank Philippa Revell and David Press for comments on a draft of the paper, and the journal's referees for some very useful suggestions. The Faculty of Commerce and Administration and the Internal Grants Committee of Victoria University of Wellington provided financial assistance (Grant 61/90). 
do occur, are to be shared out. Given the silence on this issue we have to be sceptical that there are any benefits for workers in a more flexible labour market since the flexibilities sought by employers nearly all involve losses for working people. Weekend and night working, less secure employment, intensification of work, and wages set in line with employers' ability to pay mean a lower quality of work for those workers forced to accept these flexibilities and it would require both a very substantial increase in output, and a massive redistribution of income to compensate these workers.

This paper will not be able to address all the issues raised in the flexibility debate, 1 but it attempts to shed some light on the question of how a more flexible labour market affects the quality of work. The retail sector is used as a case study. The retail industry is a particularly apposite case since it has already provided many of the flexibilities sought by employers in other sectors. Wages have declined relative to other industries; the proportion of casual employees has increased substantially; and opening hours have been progressively liberalized until now shops can open almost continuously. Despite this degree of flexibility, many segments of the industry are in a perilous state. The paper will examine the factors responsible for the industry's ailing condition, and the consequences of this for those who work in the industry.

The paper is organized into 2 main parts. It begins by examining the dynamics of the industry, the tendency towards deskilling some sections of the work force, the pay structure, and the changes to shop trading hours. The second part draws on the work of the Second Sweating Commission (1990) and looks at the consequence of these changes for the quality of work, and examines job satisfaction, casualization, juvenalization, feminization, health and safety, and finally, prospects for the future.

\section{The dynamics of the New Zealand retailing industry}

Retailing is a vast industry, divided into sub-sectors, which are not easy to define. In this paper, we restrict the analysis to retailing from the various types of "store" or "shop" but a broader definition of the industry would include restaurants, hotels, service stations, and mail order houses. The major division of the industry, as we are defining it is into food and non-food stores. This division is reflected in the award structure, for the main awards in the industry are the Grocery and Supermarket Award and the Non-food Award. The other major award is the Butchers Award. Besides these awards, there are awards for fish shops, cake shops, pharmacies, fruit and vegetable shops, dairies and mixed businesses.

Although the awards do distinguish between different types of store, the divisions are far from clear cut. Many non-food stores sell food items. Supermarkets and dairies sell a wide range of non-food items. Pharmacies sell a wide range of general goods. What is more, the picture is never static as individual shops expand their lines into new areas, and abandon old ones.

The lines carried by individual stores is only one source of change, for retailing is a dynamic industry which is being restructured continuously. Changing ownership, new products, new methods of selling, competition from other forms of consumption, and the increasing involvement of retail real estate companies generate new patterns of competition. These changes impact on the retail labour force which is continuously resegmented as these changes transform the organization of shops and the retail labour process. The internationalization of the economy plays a major part in this as foreign operators introduce new labour practices and new products. Competition with imports alters profitability and pay levels and these seriously affect the quality of work for retail workers.

1 These will be addressed in a forthcoming book P. Brosnan (ed.) Labour market flexibility in New Zealand. 


\section{The industry}

New Zealand's small population limits the retail market and the relatively large area and dispersion of population increases the difficulties of supplying that market. The development of the economy has significantly influenced the industry. The small scale of New Zealand manufacturing, and the system of import licensing that prevailed until the 1980 s, meant that most stores were reliant on the same suppliers. As happened elsewhere (Rubery et al., 1987) the relative smallness of many stores and chains reduced their power in relation to suppliers. Stores normally paid the same wholesale prices and the award system equalized wage rates. Thus all stores had similar cost structures and price differences were rare or insignificant. Competition between stores was based more on location, advertising, window display, service or the availability of credit. Trading hours were restricted to 40 hours per week from 1945 which, as we discuss below, influenced patterns of shopping and store location.

The major sectors of the New Zealand retail industry are highly monopolistic. The largest 4 operators in the major sectors of the industry employ more than half of the labour force and account for more than half the sales in that sector. Even the sectors which are noted for their low pay, such as toy and novelty shops (Brosnan and Wilkinson, 1989, table 8), have a few employers controlling most of the sales and employment of the sector. Mergers and takeovers are continually changing the structure, but the industry is probably more concentrated now than it has ever been.

Changes in products, consumer tastes, labour force behaviour, and government policy have all interacted to alter the pattern of shops and shopping. Whereas most major retailers had once been family firms, the last decades have seen the descendants of the original owners selling their interests to corporate proprietors. These corporations, in turn, have changed operations, merged with other corporations not always involved in retailing, and resold stores as strategic opportunities presented themselves. One consequence of the changes in ownership has been the decline of paternalism and the replacement of family managers, but it has also meant less job security for workers.

These changes have accelerated in the last decade as importing has been freed up and permitted trading hours have been extended. The factors responsible for the transformation of retailing have been similar to those listed by Bluestone and Stevenson's study of retailing in the United States: "virulent competition ... following the introduction of the discount mode; revolutionary change in ownership patterns ... ; and sweeping changes wrought by technological advances" (1981, p. 25-26).

The process of change, however, has intensified over the last 5 years. The retail sector has suffered very badly as a result of government policy. Various components of the Labour Government's policies directly affected the retail industry: the freeing up of importing, the removal of restrictions on foreign ownership, the liberalization of shop trading hours, reductions in real incomes and changes to the industrial relations system. The process of change unleashed by all these factors has been hastened further by the severe economic downturn which has flowed from these and other government policies. The result has been fierce competition in many segments of the market with severely eroded profit margins and a consequent deterioration of pay and conditions for workers in the industry. Six specific factors are perpetuating the pernicious competition in the industry: (a) slow growth in consumer demand (b) over supply (c) cost increases (d) poor sites (e) imports and (f) corporate weakness.

Slow growth in consumer demand The real volume of retail trade has declined by more than 10 percent over the last 15 years. Minimal population growth has left the number of consumers more or less unchanged. Alternative forms of consumption, such as restaurants, gambling, tourism, and general entertainment have developed strongly. Most important of all, there has been little growth in disposable income. 
The level and distribution of income has had real effects on retail sales. The massive growth in unemployment has contributed to a substantial decline in consumption. At the same time, real wages have fallen and, furthermore, there has been a substantial redistribution of income from the lower paid to the higher paid (Brosnan and Wilkinson, 1989). Given the greater propensity to save of the more wealthy, it was inevitable that this redistribution, plus the overall decline in incomes, would induce a fall in retail sales. This decline in demand has intensified the level of competition between stores, between chains, indeed even between different types of store, for the shrinking consumer dollar.

Over supply Most sectors of the retail industry are highly competitive within the sector, and increasingly they face competition from other sectors, including manufacturers and growers who sell direct to the public. Patterns of trade are changing within retailing too. Thus, supermarkets now sell hardware; some pharmacies sell clothes; packed meat is available at dairies while service stations sell newspapers, magazines, milk, bread and a variety of other foodstuffs. At the same time, department stores have conceded market share to specialty stores. Thus, for example, the hardware section of most department stores has been reduced drastically, while many department stores have given up selling paint or wallpaper. The only limit to this process is a legal requirement that pharmacies be owned by qualified pharmacists, but supermarket owners and other retailers are lobbying to have this law changed so that they can extend their services into prescription medicines.

Official data on retail sales, presented in table 1, highlight this shift in sales by store type. The table shows declines in real turnover for most types of store while chemists and supermarkets have experienced real increases. The vastly increased share of sales by these types of store reflects their extension from traditional products to a very wide range of merchandise. Supermarkets increased their share of all retail sales during the $1980 \mathrm{~s}$ from 24.0 percent to 38.8 percent and chemists experienced a similar increase from 3.8 percent to 6.3 percent. All other sectors apart from hardware and household appliances had their shares reduced, the greatest decline being for department stores whose share dropped from 11.7 percent to 8.5 percent, and butchers whose share fell from over 3.6 percent to below 2.9 percent.

Other changes relate to the nature of retailing real estate. With the restricted trading hours available until 1980, malls, i.e. covered shopping centres, were not such an attractive form of retail real estate. ${ }^{2}$ There were some malls nevertheless, and these benefited greatly from the advent of Saturday shopping in 1983. As Saturday shopping developed, new and larger malls were built. Thus the proportion of retailing captured by malls increased and the traditional "ribbon" shopping declined.

The development of the mall concept has seen the role of the developer/landlord expand to become a principal actor in determining the availability of shops and shopping. Before the advent of the modern mall, retail landlords played almost no part in the industry as such. They merely took rent off shops. Now, mall owners deliberately set out to create a unique retailing environment within their mall and are selective in terms of whom they accept as tenants. Rents are set as a percentage of turnover. Thus the mall owner has an interest in both the standard of the mall and its mix of shops. Furthermore, shops with low turnover, and therefore low rents, will not usually have their leases renewed. These mall owners usually set trading hours for the mall as a whole, and the usual requirement of the leases is that all shops have to be open while the mall is open. Thus mall owners are indirectly adding to the competition between shops.

2 In fact, the introduction of restricted hours earlier this century saw the demise of malls that had been built in the nineteenth century. 
Table 1: Percentage change in retail sales (constant dollar values)

\begin{tabular}{lrrr} 
Store type & $1975-80$ & $1980-85$ & $1985-90$ \\
\hline & & & \\
Butchers & -14.1 & -6.4 & -43.6 \\
Supermarkets/Grocers & 8.2 & 13.4 & 2.4 \\
Other food & 0.0 & 16.2 & -33.2 \\
Footwear & 1.9 & -8.0 & -45.6 \\
Clothing and textiles & -17.8 & -14.8 & -16.8 \\
Furniture & -9.4 & -4.8 & -27.9 \\
Household appliances & -2.1 & 21.8 & -24.4 \\
Hardware & -6.9 & 5.5 & -12.7 \\
Chemists & 3.7 & 5.6 & 10.9 \\
Department and General & -15.6 & -3.5 & -36.2 \\
Other & 1.4 & -1.9 & 7.9 \\
& & & -11.4 \\
Total & -3.2 & 3.3 & \\
\hline
\end{tabular}

Source: Monthly abstract of statistics.

This process of intense competition is continually augmented by the entry of new types of stores into the industry, and the expansion of existing stores into new lines. Entry to the industry is relatively easy, and fringe retailing can make substantial differences to the sales of some lines. Ironically, the economic downturn while reducing demand for retail goods has also added to the stock of shops, for a significant number of older, redundant workers, especially from the State sector, have used their redundancy settlements to enter the retail trade as owner operators of small shops.

Where these fringe operators are self employed, they also indirectly affect working conditions. They often impose long hours on themselves, and may sacrifice immediate income for capital growth or the development of goodwill. If they employ staff, they may demand similar levels of commitment from them. Either way, they provide a form of low wage competition for larger firms which may lead to a worsening of conditions for the staff in those firms too.

The most severe competition has come from Australian firms such as K-Mart, Just Jeans, Country Road, and Fletcher Jones which have entered the New Zealand market in the last 5 years. These Australian firms have acquired or built quality shops. Cole Meyers, reputed to be one of the largest grocery companies in the world, is the largest of the Australian firms. It has only been operating in New Zealand since 1988, but, through its acquisitions, it controls about 14 percent of the New Zealand food market. Its K-Marts are a new entry into the northern non-food market. Another Australian firm, Dairy Farm, ${ }^{3}$ recently acquired the Nathan group of supermarkets (Woolworths, Big Fresh and Associated Wholesalers) which control a further 18 percent of the market. These Australian operators, having the advantage of their links to Australian suppliers, are well placed to compete in both the wholesale and retail markets, and can demand high standards and favourable prices from New Zealand suppliers.

These Australian firms are already making an impact on working conditions as they endeavour to implement Australian working conditions. They are being selective in this

3 Dairy Farm, a listed subsidiary of Hong Kong based Jardine Matheson, owns Australia's third largest chain, Franklins, and has supermarkets in Hong Kong, Taiwan, Spain and the United Kingdom. 
though. Where Australian conditions are superior, e.g. annual leave, they prefer to apply New Zealand conditions.

Cost increases Many stores had negotiated their leases before 1987 when demand for real estate, and therefore the level of rents, was very high. Despite adjustments downwards in rents since then, most stores are stuck with leases that are more favourable to their landlords than themselves. On top of this, the entry of redundant workers into the retail sector has kept up the demand for shop leases, and kept rents at a level which may otherwise not have been sustained.

This shift in demand further hurt many downtown stores which already experienced high costs on account of their location. Many of them are located in old buildings, unsuited to modern trading. In addition, they use highly valued real estate which, in recent years, has added to their tax liabilities as land tax has been increased and the basis of local body rates recalculated.

The decline in economic activity has meant shorter production runs and higher average costs for manufacturers which has, in turn, increased wholesale prices for retailers. Other factors are adding to costs too - for example, the vastly increased use of credit cards, with a high percentage cost per transaction and a delay in receipt of the payment. Other non-traditional means of payment, such as electronic funds transfer (EFT) have also been expensive and the retailer's cost for EFT has been a continuing source of dispute between retailers and the banks.

Poor sites Changes brought about by Saturday trading are still having their effect on the geographic concentration of demand. Furthermore, other dynamic forces have been relocating the pattern of shopping. This has left a significant number of stores, particularly department stores left in sites with reduced "pedestrian counts". The leasing system, tradition, and underfunding has nonetheless caused these stores to remain on these less profitable sites.

Imports Some segments of the industry have been taking advantage of the liberalization of imports to do their own importing. The perceived cost savings, though, have generally turned out to be illusory. These firms have discovered that shipping is more specialized and delays more common than they suspected.

A recent development following the liberalization of imports has been the opening of disposal outlets or "direct import" stores which sell a limited range of low quality products, usually from third world countries, directly from packing cases. These shops usually locate in temporary premises, awaiting demolition. Their low rents, zero warehousing costs and minimal marketing give them considerable cost advantages over their technologically superior competitors.

Better established stores are making more use of alternative sources of imports too. But again the benefits are turning out to be illusory. High failure rates in alternative importing can turn an apparent profit to a loss. Nevertheless, the competition between imports and locally produced products has further squeezed profit margins in both categories.

Corporate weakness Many of the investment companies which were wiped out in the 1987 stock market crash had acquired retail companies for their portfolios. Most of these retail companies had been experiencing difficulties prior to acquisition - hence the ease of the initial takeover - but they are compounded by the now inadequate financial base of the parent companies. Although a series of mergers and takeovers is restructuring the ownership of the industry, many of the financial problems remain.

The response of management to all these difficulties has been to try to survive by competing on the basis of price. This has been accompanied in the non-food sector by escalatory advertising. The results are reductions in gross margins with even greater 
reductions in net margins. This competitive scramble has trimmed profits below sustainable levels. Small specialist shops which are able to exploit market niches are able to make satisfactory profits. But the chains and bigger shops are making losses. Although average margins in the non-food sector are in the range 20 to 30 percent (compared to about 30 to 40 percent 5 years ago), net margins are currently negative for many stores. The food sector is doing a little better. Its gross margins are in the range 4 to 18 percent which yields a net margin after tax of 2 to 3 percent for the better quality supermarkets and 0.5 to 0.75 percent for the majority.

The more successful retailers are endeavouring to compete on the basis of service, product quality and the attractiveness of their stores. Nonetheless, they still face competition from disposal outlets which can offer considerably cheaper goods, and they face many increased costs unrelated to their central operations (e.g. rent). Adjustments are being made by suppliers too. Some transnationals are buying back their New Zealand subsidiaries, or amalgamating them with the Australian subsidiary, with the aim of standardizing their products. They are also rationalizing the number of stores they supply. The outcome is likely to be more orderly marketing and better service at the top end of the market but many of the structural problems of the industry will remain for some time.

\section{Deskilling}

The restructuring of the industry itself is only one aspect of change. The last 4 decades have seen a restructuring of stores themselves. This has changed the nature of shop work and has effectively deskilled a significant portion of the labour force. Deskilling creates the possibility of reducing pay further and using more casual and teenage labour. As Bluestone and Stevenson (1981) suggest, this deskilling arises directly from employers' attempts at cost cutting. With the growth of self service, and the concomitant development of specialist advertising, the skills of expert sales staff are no longer essential. It therefore became easier to use untrained casual and part time workers, especially if they work alongside more experienced staff who can handle the more technical enquiries or do complex paperwork. Credit cards and EFT further reduce the responsibility of the assistant who once played an important role within the store's system of customer credit. Simultaneously, bar coding of products and modern cash registers eliminate most of the mathematical skills.

Beyond the cash register, mass advertising by manufacturers reduces the amount of selling that needs to be done by sales workers. Thus mass production and mass advertising have gone hand in hand with the cash-and-carry style of store. But their impact extends to other types of store too. If advertising is successful, customers enter a store looking for a particular product and the shop assistant's job often consists only of helping to find that product, if help is even needed, and in taking the customer's payment for the product. Store advertising augments this process; products advertised by the store will be placed prominently and the sales assistant's job is reduced to operating the cash

register. Thus deskilling, as well as producing a downward pressure on pay, provides employers with many of the flexibilities that they seek in using more casual labour.

Deskilling is not confined to the sales assistants. Branch manager's jobs are deskilled at least as much. One of the main reasons for introducing bar coding was to simplify and improve the level of stock control at the branch level (Smith, 1988). With centralized computer control, stock management was removed from the branch altogether. Branch managers have also lost responsibility for most other features of their stores with prices, product lines, store layout, promotions, and staff budgets all being determined centrally. Their primary responsibility devolves, therefore, to staff supervision and even this is usually delegated to supervisors (Smith, 1988). 
There are limits to this deskilling process, however, because some segments of the industry place a premium on service and product knowledge. At the luxury end of the market, the total product being marketed is not just the commodity traded but also the experience of shopping. Thus the sales assistant's knowledge, manner and appearance become integral parts of the product's perception, and even part of the product itself. The need to have knowledgeable, charming sales staff cuts across the ability of employers to completely deskill the retail labour force but, at the same time it segments the labour force.

Nonetheless, deskilling of some segments of the industry has effects on other segments since the award structure is based on a basic rate for the whole industry. Thus, as some of the work became deskilled, the perception of retail work changed from that of a semiskilled job to one which any moderately numerate person could do, and the pay became lower than that in almost any other industry. Nonetheless, pay is not clearly related to the degree of skill, for pay rates are higher in the supermarket sector (table 3 below ${ }^{4}$ ) which has been deskilled more significantly than the non-food sector. Moreover it is not clear that deskilling is the key to profitability: Smith (1988), in a British study, found that stores which retained a more traditional labour process were as profitable as those which had significantly deskilled.

At the top end of the market, workers are employed under different terms. Thus, cosmetic companies sometimes have their own employees sell cosmetics in department stores - and on a higher wage than the other cosmetic sales staff, despite the number of "badges" they might have earned. The closer the cosmetic company wants to be to the top end of the market, the more likely they are to adopt this strategy.

These changes have implications for careers in the industry. Managers, clerical staff and shop assistants are seen as comprising distinct segments of the retail labour market. Especially in the food sector, shop assistants comprise a secondary labour market. They are seen as unskilled and the mobility is generally restricted between packer, shelf filler, checkout operator and ancillary jobs such as trolley collector. Even here there is a gender division of labour in that most checkout operators are female while most shelf fillers are male. To the extent that there is any promotion, it is to jobs such as checkout controller, or price controller: Managers are recruited in a separate labour market, and although they may spend some time as checkout operators, this work is regarded as training or familiarization. The assistants are generally female, part time, and from all age groups. Management trainees are young, full time and male.

There is less segmentation in the non-food sector. At the top end of the market, where experience and product knowledge are important, it is possible for shop assistants to become supervisors or buyers. The National Certificate in Retailing is available to workers seeking a career in the industry but the scope for advancement is limited nonetheless. With the growth of large chains, skills such as buying are not needed at branch level. Accounting, or other tertiary qualifications, may provide a better route to management. The lower end of the non-food sector is being increasingly modelled on the food sector. Thus the opportunities for advancement in the non-food sector remain very limited for most workers.

\section{Trade union organization}

The retail unions have a long history. The earliest associations of shop workers were formed to achieve some control over shop opening hours. Butchers unions were

4 The difference preceded the 1990-91 wage round, when the non-food award rate was not increased. The reader will note from table 3 that, even after allowing for the 2 percent increase in the supermarket sector, achieved in the 1990-91 round, wages in the non-food sector are noticeably lower. 
formed in the late $1880 \mathrm{~s}$. A grocers union was probably formed about the same time (Hince et al., 1990). After compulsory unionism was introduced in 1936, the unions gained large numbers of members, and were able to achieve a significant financial base. As Hince et al. (1990) point out, however, the unions were never very well organized nor very active. In some respects, this reflected the conservatism of the membership, but it also derived from the stultifying effect of the industrial conciliation and arbitration system and compulsory unionism. From the $1970 \mathrm{~s}$, the unions started to rebuild and a series of amalgamations led to the formation of the 2 unions as they are at present.

The 2 major unions which represent retail workers are the Northern Distribution Union and the New Zealand (except Northern) Distribution and General Workers Union. The Northern Union covers workers north of Taupo and the New Zealand Union workers south of Taupo. These 2 unions also represent drivers and store workers in some districts. Together with some regional drivers unions and stores unions, they belong to the Distribution Workers Federation. The 2 unions are organized into regional branches and they have special structures for retail workers within them.

Unions of retail workers face immense organizational difficulties. With over 100,000 workers spread over tens of thousands of work places, it is impossible for organizers to visit each site on a regular basis. These difficulties are highlighted by the data in table 2 which show the size distribution of retail sites organized by the Northern Distribution Union. The situation is worse than this, since the union will be unaware of some of the smallest sites. These difficulties are compounded by the high rate of turnover in some sectors of the industry. Official statistics reveal that turnover in the industry has increased relative to the all industry average during the $1980 \mathrm{~s}$. The retail rate of terminations was 41 percent in 1980 when the all-industry rate was 42 percent. By 1988 , the all-industry rate had dropped to 33 percent but the retail rate held up at 38 percent (Quarterly Employment Survey).

Table 2: Retail sites organized by the Northern Distribution Union

Members

$1-5$

$5-15$

$16-50$

$51-100$

$100+$
Number of sites

7211

181

112

37

Source: Second New Zealand Sweating Commission (1990, p.33).

The difficulties faced by the unions have been compounded by the State's withdrawal from the inspection and enforcement of awards. Organization will be almost impossible if the provisions of the Employment Contracts Bill are enacted. This is particularly serious considering that the Second Sweating Commission (1990) uncovered a strong, almost obsessive anti-unionism among retail employers. This was strongest among the owners of small shops who resented any intrusion of "outsiders" into the affairs of their business. But it was also evident in the attitude of management in some large chains too.

The increasing casualization of the industry is a further problem. Even when union organizers can meet casual workers, they find it difficult to convince them that they 
should join the union (the union membership clause notwithstanding). Total union membership is approximately 38,000 out of an official retail work force of 102,000 (approximately 37 percent). Unions therefore face a strategic choice, to concentrate on the large sites, where the majority of members work, or to respond to complaints and to limit their role to essentially a fire fighting one. Either way, professional union staff are not able to fully service the membership by themselves. Thus an effective system of lay officials is crucial to the union. But even lay officials cannot cope with the problem of so many small shops - which are often the very ones least likely to honour the award.

\section{Pay rates}

Retailing has always had pay rates towards the lowest end of the industry wage distribution, but the last decade has seen pay rates decline substantially compared with other industries. Nonetheless, the award system has operated to provide some floor to wages and to provide some structure in a complex industry. In the less competitive era that prevailed before the 1970 s, the award system was largely accepted by employers; the rates set out in the awards, although only minimums, became the paid rates. Thus wage costs through out the industry were more or less standardized.

The other effect of the award system was to restrict the extent of commission selling. Since award rates had to be paid whatever the level of sales in the shop, or whatever the performance of the individual salesperson, commission selling could only be effective where the award wage constituted a minimum guarantee and total commission would greatly exceed that. Thus commission selling was mainly restricted to whiteware, brownware and electronic appliances where the value of each sale is high, and the knowledge and skill of the salesperson is crucial to the sale. This end of the market has remained a largely male dominated segment.

Shop size played a major part in the attitude of employers towards the award. The award was more likely to be breached in small shops. Although the major stores negotiated the award and always attempted to keep rates as low as possible, most of them observed most aspects of the award, especially the prescribed pay rates. After all, the publicity surrounding a prosecution for an award breach, in what was a low wage industry, would be bad for business. The large employers also used their dominance of award negotiations to gain further advantages for themselves. ${ }^{5}$

The low average hourly earnings in retailing, the lowest of any industry in New Zealand (Brosnan and Wilkinson, 1989, table 8), are partly a consequence of the youth rates in the retail awards, and the consequent juvenalization of the industry, which we discuss below. They also highlight, however, the fact that retailing has among the lowest awards for adult workers too. As examples, Brosnan and Wilkinson (1989, table 18) noted that pharmacists' assistants in the Northem Industrial District had an award with an adult rate which was no more than the statutory minimum wage. They noted that the adult rate in the Cake Shop Employees award was only \$23 a week above the minimum wage.

An idea of the current rates in the 2 main retail awards is given in table 3 . The table shows how low are the rates for all categories of retail worker compared to the average hourly rate for all industries of $\$ 14.07$. Even branch managers are poorly paid. As the table shows, after 10 years service, branch managers in the non-food sector are entitled to only $\$ 9.79$ an hour.

5 This was highlighted in the Kiwi House case, where the owner of a small tourist shop challenged the legality of the award's negotiation as only large employers were represented in the conciliation council. 
Table 3: Rates in retail awards: March 1991

$\begin{array}{lll} & \begin{array}{l}\text { Grocery and } \\ \text { supermarkets }\end{array} \quad \text { Butchers }\end{array}$

Assistants

Under $16 \frac{1}{2}$

$16_{2}^{1}$ to 17

3.67

3.86

4.38

20 or over

3.89

3.86

4.80

6.93

6.60

8.16

Departmental manager

(with buying responsibilities)

18 or 19

20 or over

6.08

7.23

8.76

8.03

20-21

8.03

Branch manager

In charge of 6

or more assistants

9.37

9.72

9.55

Branch manager

In charge of 20

or more assistants

9.37

10.99

9.55

Branch manager

(after 10 years' service)

In charge of 20

or more assistants

9.79

11.42

10.29

Source: Second New Zealand Sweating Commission, 1990.

Payment of above award wages, except for workers selling on commission, appears to be rare outside the Auckland area. Even in Auckland, above award wages seems to be only available to male workers. The only women who appear to receive above award wages work in specialist boutiques or sell top of the range cosmetics in department stores (paid by the cosmetics company) or pharmacies (Second New Zealand Sweating Commission, 1990). There is no clear link between the status associated with certain stores and the wage levels in those stores (Carter and Carter, 1985). For example, the Christchurch store Ballantynes attempts to project an image of superiority, but does not pay high wages and strongly resists any attempt at unionization. 6

The Second Sweating Commission (1990) found that underpayment was a not insignificant problem in smaller shops. Given the difficulties that unions have organizing in small shops, the extent of underpayment may be more significant than the Commission was able to determine.

6 The Second Sweating Commission heard that Ballantynes gave staff time off on pay to wave to the Queen when she toured New Zealand. Nonetheless the firm has consistently refused to give staff time off to attend union meetings even though this right is guaranteed by law (Evidence presented, 8 February 1990). 
Table 4: Percentage increases in award rates: $1987-90$

\begin{tabular}{lccccc}
\hline & Grocery & & & \\
Year & Non-food & $\begin{array}{c}\text { Retail } \\
\text { supermarkets }\end{array}$ & Butchers & $\begin{array}{c}\text { National } \\
\text { average }\end{array}$ & average \\
\hline $1987-88$ & 7.5 & 7.5 & 8.3 & 7.8 & 8.1 \\
$1988-89$ & 3.5 & 4.0 & 4.0 & 3.8 & 4.0 \\
$1989-90$ & 4.0 & 4.3 & 4.0 & 4.1 & 4.5 \\
\hline
\end{tabular}

Source: Second New Zealand Sweating Commission, 1990.

Retailing has the lowest ratio of junior to adult rates of any award. This contrasts with many other industries and occupations which have no youth rates. In fact, the nonfood award covers cleaners, lift attendants and watchpersons as well as shop assistants and there are no youth rates for these occupations. The lowest rate for these workers is $\$ 7.08$ for a first year cleaner. While this is still a relatively low rate, it applies to even 15 year old cleaners and is above the starting rate for 20 year old shop assistants. It is impossible to justify the youth rates in the retail awards on the basis of it being a trainee's rate since so very little training is now provided in the industry. In any case, apprentices in the craft occupations, who do receive genuine training, receive a higher proportion of the qualified craft worker's rate (which translates into an even higher level of wages).

Table 5: Average hourly earnings in retail as a proportion of average hourly earnings in all industriesa

\begin{tabular}{llcc}
\hline Year & Males & Females & Persons \\
\hline 1975 & 0.85 & 0.81 & 0.79 \\
1980 & 0.81 & 0.85 & 0.80 \\
1985 & 0.81 & 0.81 & 0.78 \\
1990 & 0.75 & 0.75 & 0.74 \\
\hline
\end{tabular}

Source: Quarterly Employment Survey.

Note: a Excludes agriculture.

The fall in wage rates follows the loss of compulsory arbitration since 1985 which has strengthened the employers' hand considerably. Whereas a union could previously take a dispute of interest to arbitration, now they have no means, other than the strike, to force employers to concede an award. It is extremely difficult to organize a strike among workers in small shops. Employers also have used legal devices to turn the system further to their advantage. They have managed to argue, for example, that video shops are not "lending libraries" and therefore not covered by the non-food award. The Labour Court supported this plea, arguing that libraries only lent books. Despite the fact that these video "libraries" also sell video tapes, food and other items, the union has not been able to achieve coverage under other awards. If such a decision had been made by the Arbitration Court before 1985, the union could have forced the employers to bargain over 
a new award specifically for video stores, with the threat of compulsory arbitration if the employer would not agree. The new arrangements leave things stalemated, and with video store owners holding the advantage.

The effect on retail pay rates of losing compulsory arbitration is illustrated vividly by table 4 which shows how retail wage rates have been slipping behind the movement in average pay rates. This is backed up by the data in table 5 which compares average hourly earnings in the retail sector with hourly earnings in all industries. It will be seen that retail wages have been slipping behind since the industry has been increasingly casualized following the reintroduction of Saturday trading in 1980.

Table 6: Increases and concessions in the non-food award

\begin{tabular}{|c|c|c|c|}
\hline Year & $\begin{array}{c}\text { Average } \\
\%\end{array}$ & $\begin{array}{c}\text { Retail } \\
\text { non-food } \\
\%\end{array}$ & Concession \\
\hline 1985 & 18.7 & 15.0 & - \\
\hline 1986 & 7.5 & 6.75 & - \\
\hline 1987 & 8.1 & 7.5 & Nine more trading days after 6 p.m. \\
\hline \multirow[t]{3}{*}{1988} & 4.0 & 3.5 & $\begin{array}{l}\text { Weaker proportion clause (i.e. the } \\
\text { ratio of juniors to seniors) }\end{array}$ \\
\hline & & & $\begin{array}{l}\text { Less control on the right to } 2 \\
\text { consecutive days off each week }\end{array}$ \\
\hline & & & Six more trading days \\
\hline \multirow[t]{2}{*}{1989} & 4.5 & 4.0 & $\begin{array}{l}\text { Shorter minimum hours for casual } \\
\text { workers }\end{array}$ \\
\hline & & & $\begin{array}{l}\text { A working party to review overtime } \\
\text { and penalty rates }\end{array}$ \\
\hline $1985-89$ & 49.9 & 42.1 & \\
\hline
\end{tabular}

Source: Second New Zealand Sweating Commission (1990).

Table 6 expands on the information in table 4 by analysing the movements in the non-food award since 1985 . It will be seen how pay has been progressively slipping behind average wages. But it will be further noted how employers have been able to use their greatly increased bargaining power to extract significant concessions, especially more flexible opening hours, in return for these minimal increases. Employers used their enhanced bargaining strength to demand further concessions in the 1990-91 wage round. The supermarket and grocery award and the butchers award were settled in line with the 2 percent growth agreement but with the concession that the period of notice which employers must give for opening on Sundays, nights or statutory holidays being reduced from 4 weeks to 2 . The non-food employers demanded various concessions amounting to 
the abolition of all penalty payments and the repeal of the protections provided by the Shop Trading Hours Repeal Act. At the time of writing, the award has not been settled and it appears unlikely that it will be. The implementation of the Employment Contracts Bill will undoubtedly reduce average earnings further.

\section{Trading hours}

Shop trading hours have always been of central concern to retail workers, and were subject to legislative control from 1892 to 1990 . There were 2 threads to this control. One related to the desire to keep Sunday free from commercial activity. The second related to a desire to regulate conditions of work in the retail industry (Advisory Committee, 1988).

Although controls on shop opening hours date back to 1892 , employment and opening hours were restricted from almost the beginning of British settlement in 1840 . The English Sunday Observance Act 1780, which prohibited Sunday trading, applied in New Zealand from the passage of the English Acts Act 1845. Subsequent New Zealand statutes also restricted hours. The Employment of Females Act 1873 limited the employment of females and minors, and the Police Offences Act 1884 prohibited Sunday trading.

Aside from these restrictions, there were no further controls on opening hours. Thus shop assistants had to work long hours and often unsocial hours. Butchers and some other categories of shop workers began work very early in the morning while workers in other types of shops worked to very late at night. Opening hours thus played a major part in determining the quality of life for shop assistants. An early closing association was founded in Auckland as early as 1856. Similar associations were founded in other centres within the next decades (Hince et al., 1990). Political action by the Wellington Shop Assistants Association was instrumental in obtaining the Factories and Shops Act in 1890 and the Shop and Shop Assistants Act in 1892. This struggle to control hours played a key role in the formation of shop assistants' unions (Hince et al., 1990).

The struggle to control opening hours went through a series of phases. The first phase was to gain a half day holiday. This was provided by the 1892 Act, which also limited weekly hours for women and males aged under 18 to a maximum of 58 hours per week. The next phase was to regularize the half day holiday by making half day closing mandatory. This was achieved by the 1894 Act. The third phase was to have trading hours restricted. The lobbying of the unions and the early closing associations, achieved this in 1904 (Hince et al., 1990).

The next phase, having shops shut on Saturday afternoons, was won on a piecemeal basis from the 1930s as individual local authorities changed from Wednesday half day and Saturday late-night to Saturday half day and Friday late-night (Hince et al., 1990). Once shop assistants gained the 40 hour week, Saturday trading virtually ceased. But the retail industry was one of the last to gain the 40 hour week.

The First Labour Government had amended the Industrial Conciliation and Arbitration Act in 1936, reducing maximum hours per week from 48 to 44 . The amended Act provided for a 40 hour week to be included in awards except where employers could show that their business would be unable to operate on that basis. When the retail unions lodged claims with the Arbitration Court for a 40 hour week, the employers argued that there would be difficulty operating, and this line succeeded (Hince et al., 1990, p.28). Thus hours of work in the retail sector remained at 44 per week until 1945, when the Shops and Offices Amendment Act introduced the 40 hour week.

This was the nadir of trading hours. After 1945, a series of legislative and administrative changes gradually extended the opening of retail establishments. In part, this was a response to a genuine public demand, but it was legitimizing the behaviour of storekeepers who were flagrantly breaking the law. From 1955, a list of "approved 
goods" was created which defined goods such as milk, newspapers, and basic foodstuffs which could be sold at any time. The list continued to grow and opening hours became less restricted.

Some employers attempted to trade on Saturdays or on more than one night of the week. These efforts were resisted by the unions on several fronts. Sporadic strike action took place against individual stores that were attempting to open on more than one night. Vigorous efforts were put into making representations to the Shop Trading Hours Commission and to opposing extensions to the list of exempt goods (Hince et al., 1990, ch. 4). The unions also attempted to use the collective bargaining system to gain some control over hours by negotiating penal rates for night and weekend work. From 1979 , the award provided for double time for Saturday work. Despite these efforts by the union, Saturday trading was reinstated in 1980 by an amendment to the Shop Trading Hours Act.

The pressure for Saturday trading had come from several directions. The Sunday News had campaigned for Saturday trading in 1975 and the National Party, when it regained power in 1975, promised that it would allow shops to open all day Saturday. Retail employers on the other hand, were divided on the issue. Most of the large stores were opposed to it.

The changes in opening hours were also linked indirectly to women's changing labour force participation. When the 40 hour week was introduced into shops in 1945 , the proportion of married women who worked full time was only 18 percent. Thus it was practical for most families to get their shopping done during normal working time or on Friday nights. At the same time, the restricted hours of opening made it difficult for married women to work full time. As women's labour force participation increased, it had 2 effects. On the one hand, it increased the demand for shopping outside of normal work hours. On the other hand, the increasing participation provided a supply of women available for work in the retail sector and who might be prepared to work the less conventional hours that extended opening demanded.

Shop workers and their unions appreciated the potential effects of Saturday trading and fought the proposed change bitterly. Most shop assistants had secure full time jobs and, since shop opening hours had been restricted to 5 days for 35 years, there were very few left in the industry who had ever worked a 6 day week before. Polls of retail union members showed that upwards of 97 percent were opposed to Saturday trading. Nine out of 10 also indicated that "being forced to work on Saturdays would adversely affect their family life ... and their recreational activities" (Hince et al., 1990, p.48). More to the point, 9 out of 10 indicated they were prepared to take industrial action over the issue. The intensity of feeling over the trading hours issue was indicated by the campaign against the 1977 Shop Trading Hours Bill. "... mass meetings, marches, stop works and strike action ... underscore(d) the intense feeling roused among shop employee unionists" (Hince et al., 1990, p.49). Despite these protests, the National Government pushed ahead with the changes.

The return to Saturday trading in 1980 completely changed the nature of shopping and of retail employment. Saturday, especially Saturday morning, became a major trading day. Furniture and appliance retailers found that it was also a day when families browsed. Thus, even if a sale was not concluded on the Saturday, a sale later in the week may have originated from the Saturday visit. As Saturday trading developed, the pattern of demand began shifting from the original hours of 9 a.m to 1 p.m. to a concentration around the latter part of the morning. Shops, especially in the central business district, responded by opening later. A tendency developed, especially in the suburbs, to close later. Thus shop assistants found that they were not even getting a full half day off on Saturdays.

Saturday trading also changed the geographical pattern of demand. The demand on Saturdays became concentrated in suburban shopping centres, while the week day demand was concentrated in the central business districts. Thus the net effect of Saturday trading was to shift demand to the suburbs away from the central business districts. This reduced 
turnover at other times of the week, and the demand for Friday night opening diminished. Once shopping was extended to the weekend it required many shop workers to accept a 6 day working week. It also opened the way for the wholesale casualization of the industry, especially in suburban shops which needed a greatly augmented work force on Saturdays.

Once Saturday trading became firmly established, pressure began to mount for Sunday trading as well. Ironically, the pressure for this came from some of the retailers that had sought Saturday shopping a decade before. It also came from the operators of "flea markets" and from the real estate companies that owned malls. There was less than full support for retailers for any further extensions to hours. Many opposed deregulation, seeing it as longer hours and higher overheads for the same level of sales.

Most of the trading in flea markets took place on Saturday, and stall holders knew that if they could trade on Sundays as well their turnover would increase very substantially. Flea markets challenged the system, on several occasions, by opening on Sundays and accepting the fines imposed. They pointed to the high level of patronage that they had enjoyed on these well publicized occasions as proof of a general desire for Sunday trading. Real estate companies had a very direct interest in Sunday trading, since shop rents in malls were set in relation to turnover. What is more, leases for mall shops usually specified either that all shops had to be open if the majority opened. Thus mall owners could hardly lose if trading hours were increased.

The Minister of Labour appointed an Advisory Committee on the Shop Trading Hours Act in 1988. The parties appearing before the committee tended to either support retention of the existing law or else its total repeal. The Committee, comprising as it did a representative of the Distribution Workers Federation and the Retailers Federation with a member of the Shop Trading Hours Commission, was unable to recommend between these competing views.

Despite the indeterminacy of the committee, the Labour Government decided to deregulate hours anyway. By 1989, the political climate had changed considerably. Whereas in 1980 the justification for introducing Saturday trading had been the needs of the public for more shopping hours, with a recognition that change would adversely affect retail workers, the justification in 1989 was that the economy and the labour market needed to be deregulated. Sunday trading was to be a blow for labour market flexibility.

In late 1989, the Government introduced the Shop Trading Hours Repeal Bill which allowed for 24 hour trading on 365 days of the year. Thus it represented a return to the situation which applied before 1845 . Even before the Bill had been through Parliament, the Minister of Labour used regulations to allow 7 day 24 hour trading over the preChristmas period. These regulations were used to extend the period of unlimited opening through 1990 until the Bill was passed in July.

Sunday trading seems to be developing much faster in New Zealand than it did in Scotland when Sunday trading was legalized there. Although the majority of shops are not opening on Sunday during the main part of the year, the proportion is increasing rapidly. Most supermarkets are now trading on 7 days. New malls are opening 7 days and the majority of shops opened every day of the week during December 1989 and again during 1990.

The Shop Trading Hours Act Repeal Act 1990, enacted in July, made a small concession on opening hours in that no trading was permitted on Waitangi Day, Good Friday, Christmas Day or before $1 \mathrm{pm}$ on Anzac Day. It also offered certain protections to workers which were to be written into awards or agreements. In essence, the protections were to guarantee that existing workers should have first choice of any night or Sunday work, that workers could not be forced to work at night, on Sundays nor on public holidays, and that employers would provide personal security when a worker works at night, and transport when public transport is not available. By putting these protections into awards, the Government passed their enforcement onto the unions, thus abrogating any role for the State in their enforcement. Furthermore, the protections only apply to workers covered by the award or agreement. Retail workers who could not get 
an award, such as assistants in video shops, therefore lost twice. They have no guaranteed wage, other than the statutory minimum, and they have no protection against being forced to work at nights or on Sundays.

The deregulation of trading hours is virtually complete. The protections in the Act do not amount to much. Sunday working has not become a matter of choice for workers. When a worker applies for a job in the retail industry, they are asked whether they will be prepared to work on weekends. Workers know they will only be offered the job if they say they are prepared to work. There are subtle pressures on established workers to work on weekends too. Employers make appeals to company loyalty; not being prepared to work on weekends is a sign of "disloyalty". There is also the strong feeling of letting down one's co-workers. If the others do not want to work on Sundays, it seems selfish to refuse and increase the number of Sundays that others are forced to work.

\section{The quality of work}

\section{Job satisfaction}

As we discussed above, the contemporary New Zealand industry is characterized by intense competition and structural instability which is reshaping the organization of work, and reducing pay and the quality of work for most shop assistants. Many retail employers have gone into "survival mode" and their emphasis is almost solely on the return on investments. Thus training is being neglected throughout most of the industry. This compares to related industries such as motor parts where there is a strong emphasis on training. Emphasis in the retail sector is on newer technologies, and centralized purchasing and marketing. There is no place in most managers thinking for training, job enrichment or worker motivation. Job satisfaction is minimal when retail workers are instructed "tell don't sell".

Workers are increasingly being demoralized by the poor performance of their industry. And the deskilled management methods are responsible for much of this. There is little communication from managers to the workforce. Very few workers have a clear job description. And many managers have little experience in the industry. Overseas ownership, and the lack of indigenous experience by foreign managers, is compounding the problem.

The effects of these policies were stressed very strongly by the workers who appeared before the Second Sweating Commission (1990). They explained how they were experiencing a loss of self esteem. This was so particularly for workers who had been in the industry for a long time. They were humiliated to discover that their employers saw them as disposable units in the quest for profits. They "despise themselves for having to be so subservient but the overriding fear of unemployment forces them to accept the degrading treatment to which they are subjected" (Second New Zealand Sweating Commission, 1990, p.35). Problems of racism, sexism, ageism were frequently reported and the Commission heard of workers being disciplined for being too fat. The Sweating Commission was unable to find a reason for management's pettiness.

The workers themselves were unable to suggest possible motivation. While ... such management tactics were the result of lack of training and showed the insecurity of the person concerned, the effect on the workers was the same: loss of self confidence and personal esteem, fear, subservience, broken spirit (Second New Zealand Sweating Commission, 1990, p.36).

The cause of management pettiness can be traced most probably to the deskilling of the manager's job discussed earlier. As the range of factors over which branch managers have discretion is reduced, their job satisfaction is diminished. Staff discipline is one of 
the few issues over which they can exert their authority and it is no surprise that they become obsessed with staff matters and behave in an authoritarian manner.

Retail workers derive considerable satisfaction from their interaction with the public and from being able to help customers with their purchases. Tighter budgeting, understaffing and the increased pace of work make it impossible for many shop assistants to give the level of service that they would like to provide.

Longer trading hours are having particularly ruinous effects on the life of many retail workers. These were graphically highlighted by witnesses appearing before the Sweating Commission (1990). The witnesses particularly mentioned the loss of time spent with families, the increased stress within marriage, the inability to socialize with friends and neighbours, the impossibility of playing organized sport. Adult witnesses commented how this loss of sporting or leisure opportunities affected the personalities of teenagers who worked on weekends.

While these longer hours are reducing the quality of work for the existing workers, they are creating conditions where employers can recruit from other segments of the labour force. Thus employment in most sectors of the industry is becoming increasingly casualized, and increasing use is being made of women and teenagers. These same changes have greatly affected career opportunities for permanent employees who are being asked to work more intensely and have the added responsibility of supervising the casual employees while doing the jobs that employers have not been able to deskill. As a consequence, the concept of a career in the industry is disappearing for the majority of workers, and training in the industry is running down. ${ }^{7}$

\section{Casualization}

It has been observed overseas that extending shop trading hours increases the proportion of part time jobs in the industry (Beechey and Perkins, 1987). This has certainly been true in New Zealand. The changing pattern of demand following from the liberalization of hours has increased the attraction to employers of using part time and casual labour, and it has gone in hand with the increased availability of casual labour at the times of peak demand. Table 7 illustrates the growth in part time employment which has increased more than 60 percent since trading hours were liberalized in 1980 . The increasing casualization has undoubtedly paid a part in the relative increase in labour turnover in the industry which we discussed above.

As we noted above, the organizational problems which confront the unions are compounded by the increasing casualization and turnover of the industry. Casualization also affects the quality of work of permanent workers. The effect of penal rates and longer opening has been to move some jobs to the weekend and to leave other jobs for the week. Some jobs like shelf filling can be done during the week either by casual or by full time workers. Other jobs such as ordering and doing the paper work can be left to the main part of the week. This last change has added considerably to the burden of full time workers in the non-food sector. Since Saturday is a busy trading day, and a time when families do their initial inspection of goods, it is also a day which generates a lot of inquiries. Thus full time workers are faced on Monday morning with a substantial pile of inquiries and uncompleted paperwork from Saturday's trading.

7 Evidence presented to the Second New Zealand Sweating Commission from Manakau Polytechnic showed how severe the decline in course attendance has been since 1987 (Evidence presented, 12 February 1990). 
Table 7: Employment in the retail industry

\begin{tabular}{|c|c|c|c|c|c|c|}
\hline \multirow[b]{2}{*}{ Year } & \multicolumn{2}{|c|}{ Full time } & \multicolumn{2}{|c|}{ Part time } & \multicolumn{2}{|c|}{ Proportion } \\
\hline & Male & Female & Male & Female & Female & Part time \\
\hline 1975 & 30650 & 29393 & 6231 & 18655 & 0.57 & 0.29 \\
\hline 1980 & 31414 & 29200 & 5990 & 21668 & 0.60 & 0.31 \\
\hline 1985 & 32805 & 32582 & 7638 & 25845 & 0.59 & 0.34 \\
\hline 1988 & 31730 & 30987 & 10158 & 29451 & 0.59 & 0.39 \\
\hline $1990^{a}$ & 33293 & 28104 & 14950 & 30073 & 0.55 & 0.42 \\
\hline
\end{tabular}

Source: Quarterly employment survey

Note: a Data collected on a different basis than in previous years.

\section{Juvenalization}

Changes in opening hours, decreased profitability, and penal rates in awards have induced employers to make more use of juvenile labour. Junior rates are so low that employers can hire a 15 or 16 year old at double time on a Saturday for about the same wage as an adult receives during the week. The Second Sweating Commission (1990) heard of 14 year olds working from 4 p.m. to 8.30 p.m. 2 or 3 nights a week and all day Saturday. Other evidence revealed that employers were requiring children to take time off school to attend training for checkout duties. Employers have used their increased bargaining power to exploit this further by forcing the unions to concede a weaker proportions clause (table 6). Proportion clauses are of long standing. The Wellington Shop Employees Union took a case to the Arbitration Court in 1938 arguing that the proportion of seniors to juniors should be 3 to 1 compared to the existing 2 to 1 . Hince notes that small shops supported this claim because they believed that large stores, who were better placed to make use of junior labour had an unfair advantage over them (1990, p. 29). Since then, the ratio has worsened to 1 to 1 and the proportions are calculated on a weekly basis rather than on an hour by hour basis.

Some shops, particularly supermarkets make maximum use of juniors and hire them rather than older workers. These juniors though are entering a dead end job which the employer expects them to quit before they get too old. This employer strategy creates its own success. The low pay and zero prospects induce these juniors to leave when they find a better job (or even if they cannot) and their places are taken by other low paid juniors. Where juniors stay on, it is not unknown for them to be fired when they approach the age at which they would be entitled to an age-related increase or a service increment. These junior workers are often the ones underpaid below the award minimum.

Working in the retail industry has many effects on school children. Because they find it easy to get jobs in the industry, they come to believe that they can easily get jobs in other industries too. Thus they are more inclined to leave school with less education, and with these false expectations. Their experience as youth workers in this industry also shapes their expectations with respect to other jobs. Many of them are unaware of the provisions of their award and do not realize that the pay they received for night and weekend work was double the normal rate of pay. But, on the basis of their experience, they expect that when they begin full time work they will receive the same or higher pay. They also come to believe that the poor conditions, arbitrary management, lack of an 
effective union presence or sexual harassment are normal features of the industry or of work in general.

Working part time in the retail industry can begin to create a pressure to drop out of school. The assistant principal of a large girls' school wrote to the Second Sweating Commission (1990) that when school competed with paid work, all too often school lost: "we call it the Foodtown Syndrome".

Another teacher wrote to the Commission:

I realise that for many of the students who work there, the income is an important source of independence and a welcome contribution to homes where their socio-economic status has consistently been eroded by economic policy. Nevertheless, from a teacher's perspective, it severely limits the students' time to do homework and study which in turn affects their academic performance. Ultimately they revise their future education and career choices to remain in supermarket employment because it is seen as better than no job at all (Second Sweating Commission, 1990, p.18).

\section{Feminization}

Some segments of the retail industry are highly feminized while other segments have a very low proportion of women. Employers use men and women workers to provide flexibilities in different ways. Whereas flexibilities in male employment are generally obtained by having men in full time employment work overtime or accepting some functional flexibility, flexibilities in female employment are obtained by having women work on a part time basis and by varying the hours and numbers of these women (Beechey and Perkins, 1987).

Limited opportunities for part time work and discrimination against women in other sectors of the economy maintains a supply of women available at the low wages offered in the retail trades. As unemployment has risen, the availability of full time jobs has declined everywhere and part time employment is the only option for many married women who have no access to social welfare benefits. The construction of many jobs within the industry as "women's jobs", especially the part time ones, further reduce the opportunities for women within the industry for these are usually dead-end jobs. They rarely provide access to the more senior positions such as buyer or manager except in "female" areas such as women's clothing, and even here these positions are usually reserved for full time workers. Part time workers are the most vulnerable, they are less likely to be union members and thus have less protection from unscrupulous employers. Even the better employers do not always allow part time workers the same privileges as full time workers.

Overall, the proportion of women in the retail labour force increased a little when Saturday trading was reintroduced in 1980 , and was fairly constant at about 60 percent of the labour force until 1988. It may have dropped since then as the trend to juvenalization developed and teenage males, whose hourly rate is about half that of adult women, seem to have been preferred for part time jobs. ${ }^{8}$

It is probable that one outcome of repealing the Shop Trading Hours Act 1977 and enacting the Employment Contracts Bill 1991 will be that women will make up the majority of the retail labour force on Sundays and at nights. But this will not necessarily increase the quality of their working lives. It is argued by some of the proponents of more flexible hours that there will be more employment for women, and that this will add to these women's enjoyment of life. They make these arguments on the assumption that all women have husbands who will mind children. The actual outcome may well be

8 Table 7 and correspondence from Senior Manager Economic and Business Surveys, Department of Statistics, to author, 14 December 1990. 
an increased burden for these women who will have to combine iong hours at work with traditional female roles.

As the liberalized hours become established as the norm, employers will intensify their demands for penal rates to be abolished or reduced, and therefore the reward for working these less favourable hours will be reduced too. Thus, the relative earnings of women will reduce as well. Beyond these concerns, there is a danger that the greater availability of casual or part time work might be used as justification for further reducing or removing access to social welfare benefits for solo parents.

\section{Intensification}

Casualization has gone hand in hand with an increasing intensification of work. Intensification is directly related to opening hours. As the hours of opening lengthen, managers employ fewer workers at any one time. What is more, the increased costs associated with the longer hours are a further reason for employers economizing on labour costs by a deliberate policy of understaffing. Casualization fits in well with such a policy since casual and part time workers complete their shorter hours before they reach the fatigue barrier, and before they are entitled to a paid break.

As profitability in retailing has declined, most stores have reduced staffing levels. Staff that left have not been replaced and remaining staff have been expected to work harder. Evidence given before the Second Sweating Commission (1990) revealed that some managers pressured staff into working through tea breaks and lunch hours. Sales workers who sold whitewear and brownware were expected to make deliveries or service calls on their way to and from work. In the non-food sector, many workers are expected to attend "product knowledge" sessions held before work, or immediately after work. The Second Sweating Commission (1990) heard about a number of employers who expected their workers to attend these sessions without pay.

Some of the managers involved gave evidence before the Commission. They indicated that they believed this intensification to be counter-productive in the longer term, but they were forced by their superiors to go along with such strategies. In many cases they were forced to adopt these strategies because they were given target wage bills (as a percentage of turnover) which they had to meet. The only way they could achieve these targets was to manage with less staff.

An indication of the degree of intensification is provided by the target wage bills reported to the Second Sweating Commission (1990). Departmental managers from supermarkets reported to the Commission that they were required to keep wage bills in their department below 6 percent of turnover. Subsequent investigation by the author has found "superettes" that aimed for an even lower wage bill - 3 percent.

\section{Health and safety}

Many retail jobs have become tediously repetitive and a source of repetition strain injury (RSI). Using a pricing gun continuously is one source of the syndrome. Butchers are becoming more prone to RSI too as butchering is being continuously deskilled. Butchers now carry out a reduced variety of tasks and, in supermarkets, may repeat a simple operation for a very long time. Sausage making, with its repetitive twisting motion, often causes RSI. But other butchering tasks have become very repetitive too. Butchering is partly performed in abattoirs, and partly in the supermarket. Meat now comes to supermarkets, partly butchered, in $20 \mathrm{~kg}$ packs, and a butcher may spend the whole day repeating a simple cutting motion.

Checkout operators are especially prone to RSI. Initially this illness occurred in the hands as a result of keying in prices on cash registers. Bar coding has not eliminated this 
problem. It has merely changed the part of the body being affected. Now the problem is becoming one which affects elbows and shoulders as heavy items (e.g. 2 litre tubs of ice cream or large joints of meat) ${ }^{9}$ are moved across the scanners. This problem is exacerbated by the poor design of checkout stations in some supermarkets.

Draughts are a further problem affecting supermarket checkout operators. Checkout stations are inevitably close to exits, and cold draughts come in as the doors open and shut. Therefore it is not surprising to find that operators suffer a lot from colds and flu.

Many of the health problems from which retail workers suffer arise from the less scrupulous employers evading the requirements of health and safety legislation. They also evade other basic requirements in their attempts to cut costs, such as not providing facilities for eating, not having a sick room or using it to hold stock. The winding down of the Department of Labour's inspectorate, and the difficulties unions have in gaining access, permit these abuses to continue and spread. In some respects, the quality of working life has not improved in 100 years. The 1890 Sweating Commission had heard complaints that retail workers were not allowed to sit at work. The Second Sweating Commission heard similar complaints in 1990 (1990, p.20).

\section{Prospects}

The way the retail industry develops will significantly determine the quality of life for shop workers and their families. If the present course of development continues, foreign operators, especially Australians, will play a major role in the industry. Most probably, the industry will become divided into a top and a bottom, with the top comprising stores that sell high grade merchandise, market it attractively and offer good service. The bottom would comprise stores that offer lower quality products, minimal service, and which compete solely on the basis of price. This structure would be completed by a range of small specialist shops which would continue to service market niches. Whether these shops would be independent operators is another issue, for, if current trends continue, it is likely that many of these would be franchise operations.

The trend towards franchising is likely to accelerate as the growth of consumer legislation puts a greater onus on the retailer, and newer developments such as the use of electronic data interchange (EDI) becomes the normal form of ordering and invoicing. The development of consumer legislation may play a role too in further segmenting the retail labour market. As consumer protections develop, retail staff will be required to provide accurate product information. In service oriented stores this will have to lead to increased staff training for this role. At the other end of the market, it may lead to further deskilling as all consumer information is provided in written form and retail assistants, who have already had their jobs reduced to checkout operating, or shelf filling, are forbidden to comment to customers on the qualities of products.

Newer technologies present further opportunities for deskilling and destaffing. For example the use of computerized scanning has the potential to measure the rate of throughput for individual checkout operators (Smith, 1988). The data collected could be used to further hone staff numbers at periods of reduced demand. There is even the possibility of using piece rates based on the number, or value, of scans completed.

The advent of Sunday trading is increasing the pressure for changes to the current wage structure. The Employment Contracts Bill, if enacted will make this easy for employers to achieve. The provisions of the Bill will make it very difficult for unions to organize and their bargaining power will be reduced further. Employers will endeavour to abolish penal rates. The outcome, in the better shops, may well be a standard hourly

9 Irregular objects such as joints of meat are a particularly serious hazard since they do not always scan successfully. Thus 2 or more attempts may be needed before the price is registered. 
payment for 7 days of the week. A normal week might comprise any 5 days out of the 7 , with a premium for working unsocial hours. Overtime rates would be payable for working a sixth day or longer hours on a standard day. In the worse shops, there may be no overtime rates at all.

The quality of work will certainly decrease for most workers because it will be difficult to avoid working unsocial hours. Even worse, as hours of opening lengthen, employers may endeavour to cut costs further by utilizing split shifts. Many workers would be required to work on 1 , and possibly 2 , weekend days with their days off during the week. It is even possible that once Sunday trading becomes fully established, shops might close on Monday or another week day. These changes might halt the tendency towards casualization, but, if penal rates disappear, they would reduce the income of those workers who were forced to work on the weekend.

The most significant change to the industry will come if trends towards more casualization and juvenalization continue. If the Employment Contracts Bill 1990 is enacted, the unions' memberships will be seriously eroded. But, either way, it will be worse if the industry becomes more casualized. The more casualized the industry, the harder it will be for unions to organize and therefore the lower their memberships. The lower their memberships, the lesser their resources, and therefore the lesser their capacity to enforce existing agreements or to negotiate new ones. It will become much easier then for unscrupulous employers to further exploit retail workers.

\section{Conclusion}

The retail industry is going through a difficult time, but as the first section of the paper demonstrated, the causes of those difficulties are complex and beyond the control of many firms in the industry. The persistence of these difficulties highlights the limitations of labour market flexibility as a panacea for the more general problems that beset particular firms, or even whole industries. Despite virtually unlimited trading hours, the possibilities of labour substitution offered by deskilling, the decline in real pay levels achieved since 1984, and the structure of the industry making trade union organization extremely difficult, most segments of the retail sector are still in a perilous state. If anything, the advantages which the current state of the labour market offers to retail employers is perpetuating the existence of badly managed shops, or shops in poor locations. Although these shops remain unprofitable, the implicit subsidy they receive from their workers' low pay and intensified work is delaying their inevitable closure.

Against the limited benefit to employers of these flexibilities is the cost to workers in the industry, to their families and to society. The costs to workers include reduced job satisfaction, the disappearance of career opportunities, an increased pace of work, having to work at unsocial hours, continually reducing levels of real pay and the pain of RSI. Their families have to share, directly and indirectly in some of these costs and, in addition, have their lives disrupted by having husbands, wives or children having to work at inconvenient times and having time together as a family eroded by the demands of the industry. Society in general also shares these costs. The juvenalization of some sectors disrupts schooling and weekend trading makes playing organized sport impossible for thousands of teenagers. Moreover, the public health system has to deal with RSI and other illnesses which result from the organization of shop work. Shop customers gain little if anything from the abolition of legal regulation. They have to contend with less service as shops become more thinly staffed, or move increasingly to self-service. The only benefit to society is an extension of shopping hours; a benefit which surveys showed most people did not want (Advisory Committee on the Shop Trading Hours Act, 1988).

The future of the New Zealand retail industry will not be determined by changes in the degree of labour market flexibility. Sacrifices forced onto groups of workers will do 
little to stem the decline of sub-sectors of the industry or of particular firms. Rather the future structure of the industry will be determined by the dynamics of competition within the industry, changes in the whole economy and international trends. It is these factors which will determine which firms survive and which firms disappear.

\section{References}

Advisory Committee on the Shop Trading Hours Act 1977 (1988) Report. Wellington.

Beechey, V. and Perkins, T. (1987) A matter of hours: women, part-time work and the labour market. Cambridge, Polity.

Bluestone, B. and Stevenson, M.H. (1981) Industrial transformation and the evolution of dual labour markets: the case of retail trade in the United States. In F. Wilkinson (ed.) The dynamics of labour market segmentation. London, Academic Press.

Brosnan, P. and Wilkinson, F. (1989) Low pay and the Minimum Wage. Wellington, New Zealand Institute of Industrial Relations Research.

Carter, M.J. and Carter, S.B. (1985) Internal labor markets in retailing: the early years. Industrial and labor relations review 38(4):586-598.

Dannin, E.J. (1990) Examining employer proposals for labour law reform: an American perspective. New Zealand journal of industrial relations 15(2):161-178.

Harbridge, R. and McCaw, S. (1989) The first wage round under the Labour Relations Act 1987: changing relative power. New Zealand journal of industrial relations 14(2):149-167.

Hince, K., with Taylor, K., Peace, J. and Biggs, M. (1990) Opening hours: history of the Wellington Shop Employees Union. Wellington, Central Distribution Workers Union.

New Zealand Planning Council (1986) Labour market flexibility. Wellington (Economic Monitoring Group Report No.7).

Quarterly Employment Survey (series)Wellington, Department of Labour.

Quarterly Employment Survey (series)Wellington, Department of Statistics.

Rubery, J., Tarling, R. and Wilkinson, F. (1987) Flexibility, marketing and the organisation of production. Labour and society 12(1):131-151.

Second New Zealand Sweating Commission (1990) Across the counter: the lives of the working poor in New Zealand. Wellington.

Smith, S. (1988) How much change at the store?: the impact of new technologies and labour processes on managers and staffs in retail distribution. In D. Knights and $\mathrm{H}$. Wilmott (eds.) New technology and the labour process. Houndsmills, Macmillan.

Sweating Commission (1890) Report. Wellington.

Treasury (1984) Economic management. Wellington.

Treasury (1987) Government management. Wellington.

Case

Kiwi House $v$ New Zealand Shop Employees IAOW [1979] Arbitration Court Judgements 167-170. 